\title{
FIRST SASKATCHEWAN RECORD OF THE RUFF
}

by Frank H. Brazier, Regina

At 4:30 p.m. Saturday, May 8, 1965 I chanced to stop by a slough at Monica Farm, near Richardson, Saskatchewan, about six miles east of Regina. There were a few shorebirds there, mainly Lesser Yellowlegs (Totanus flavipes), and as I scanned a small flock of these about 100 feet away an unusual wader walked into the field of view of my $10 \times 50$ binoculars-a pigeon-like bird on long thick orange legs with a bright yellow bill, and thick barred neck. It was evidently very hungry as it fed from the surface of the shallow water with the utmost concentration, never pausing. I hadn't the faintest idea of what it was although the shaggy feathers on the neck made me think of a Ruff. I dismissed this thought immediately as altogether too improbable, both because of the range and because I remembered that Peterson's Field Guides had shown a dark bill. All the pictures I had ever seen of a Ruff showed the neck ruff raised and thus I did not know what it looked like with the ruff in repose.

Knowing I needed help in identifying this bird I drove furiously back to Regina. Although Elmer Fox was at home he could not come out at once, but I found Dr. Robert Nero and Robert Taylor setting up a mist-net on Wascana Marsh, and they returned with me. Back at the slough we were relieved to find the stranger still there, still avidly feeding on the abundant insect life of the slough. Dr. Nero was immediately convinced it was a male Ruff (Philomachus pug$n a x)$. Leaving Taylor to try and get photographs we went in search of a gun and eventually borrowed one. Then Elmer Fox, his wife and son, Doug, arrived.

For a long time the bird remained out of range, occasionally raising its ruff in display to a yellowlegs, and twice we thought we had lost it when the whole flock took wing, but finally it was shot, the specimen providing positive proof of the occurrence of this species in Saskatchewan.

I found I had a number of books describing the Ruff. Each stressed the wide variety of neck ruff patterns, Benson (1960) being typical: "The
Ruff has suffered persecution and is now only a migrant [in U.K. - Ed.] seen chiefly in spring and autumn. It is a remarkable bird with greatly varying plumage. The ruff and eartufts of the male are worn only in spring and vary in colour. They may be red, yellow, black or white, barred or plain, and are extended in display. At other times of the year the plumage resembles that of the Reeve (female). She is $2 \frac{1}{2}$ inches shorter and her plumage is mottled grey-brown shading to white beneath. The colour of the legs varies from grey-green to bright yellow or orange." The pictures indicate a resemblance between the reeve and the yellowlegs, and Peterson (1947) comments that this species: "usually associates with Yellowlegs."

The breeding range of the Ruff is northern and central Eurasia. It winters south to southern Africa, Ceylon and Borneo. The birds turn up in America fairly regularly. Peterson (op: cit.) says: "Over thirty records; recorded almost annually on coast in recent years." The A.O.U. Check-list of North American birds (1957) notes occurrences inland to southern Ontario, Ohio, Indiana and Iowa. Since 1957 there have been at least two records well inland, viz. one on May 15, 1959, reported by Roboins (1959) near Norway Grove, Wisconsin, and one on May 23, 1964 near Alberta, Minnesota reported by Strubbe (1964), but our bird is the only record west of the Mississippi and thus for western North America, if we disregard the occasional occurrence of Siberian birds on the Alaska coast. It is also the first European wanderer ever recorded for Saskatchewan.

It is fascinating to speculate on how a European bird came to be so far off course as this one. Possibly it crossed the North Atlantic during fall migration, worked south to spend the winter in its accustomed latitude, then associated with the reeve-like Lesser Yellowlegs and accompanied them up the Mississippi flyway to Regina this spring; or it may have been wind-blown across the South Atlantic while going north from wintering in southern Africa, and then 
fallen in on the American side with the northward moving Lesser Yellowlegs, which winter as far south as Argentina.

\section{LITERATURE CITED}

A.O.U. Committee. 1957. Check-list of North American birds. Fifth ed. Baltimore.

Benson, S. V. 1960. The Observer's book of birds. Frederick Warne, London.

Peterson, R. T. 1947. A field guide to the birds. Houghton Mifflin, Boston.

Robbins, S. 1959. A Ruff in Wisconsin. The Passenger Pigeon, $21: 73$.

Strubbe, E. H. 1964. The Ruff. The Loon, 36 :53-55.

\section{SIBERIAN RECOVERY OF PECTORAL SANDPIPER}

by C. Stuart Houston, Saskatoon *

A Pectoral Sandpiper (Erolia melanotos), number 502-86246, was shot on May 28, 1963 near Yanskij (110 $\mathrm{km}$. $\mathrm{N}$ of Verkhoyanshi), Yakut, U.S.S.R., about $68^{\circ} 30^{\prime} \mathrm{N}$. and $134^{\circ}$ $45^{\prime}$ E. I had banded this bird while mist netting at dawn for Common Snipe (Capella gallinago) on Sept. 20, 1961, 18 miles east and 3 miles north of Saskatoon, Saskatchewan. I was assisted on that occasion by J. Bernard Gollop, waterfowl biologist with the Canadian Wildlife Service, and Robert Folker, upland game biologist with the Saskatchewan Department of Natural Resources.

Yanskij is some 1560 miles west of the westernmost tip of Alaska, on the Yana River just north of the Arctic Circle; via the Bering Straits it is about 3800 miles northwest of Saskatoon.

Since the breeding grounds of this species (A.O.U. Check-List, 5th edition) extend across northern Siberia to the Taimyr peninsula, one thousand miles further west, it was quite possibly on its breeding grounds when shot. Its wintering grounds extend from Peru, southern Bolivia, northern Argentina and Uruguay south to Patagonia, whereas it is only casual in Samoa, Australia and New Zealand. It seems possible that Pectoral Sandpipers nesting in Siberia regularly travel up to 2500 miles east before beginning their long southward journey, which may extend another 7200 miles beyond Saskatoon, into South America. The largest migratory movement is east of the Rocky Mountains and the Pectoral is one of the common sandpipers in migration in Saskatche- wan each spring and fall. If allowed to indulge in even more speculative theorizing, one could estimate that the total round trip might approach 22,000 miles, rivalling that famous traveller, the Arctic Tern, (Sterna paradisaea). Extensive banding on the breeding and wintering grounds might prove fruitful.

Allen J. Duvall, then head of the Bird Banding Laboratory, informs me that 1008 Pectoral Sandpipers were banded up to and including 1960, and that the only two previous recoveries were from the state or province where banded (Illinois and Manitoba).

I have had only one other Siberian recovery - a Pintail (Anas acuta) banded June 26, 1957 at Beaufield Marsh near Kerrobert, Sask. and shot May 21, 1961 near Anadyr', Chukotka, U.S.S.R.

* Reprinted from Bird-Banding, $36: 112-113$,
April, 1965 .

\section{SANDHILL CRANES FLYING WITH FEET DRAWN UP}

by Fred G. Bard and Fred W. Lahrman,

Saskatchewan Museum of Natural History

On April 13, 1961 we visited the north end of Last Mountain Lake to get prairie sod for a coyote habitat group. It was a bitterly cold day with a strong northwest wind, rain and snow flurries. We found numerous Sandhill Cranes resting in flocks at a frozen spring. As we watched, cranes arose and circled overhead, and we were surprised to see nine cranes flying with their feet drawn forward in such a way that they appeared to have no legs. Instead of flying with their legs extended, trailing behind their tails in the usual manner, they had their feet drawn forward and tucked into the belly plumage. On two occasions we saw such birds suddenly straighten their legs out, assuming their usual appearance. We guessed that they were flying with their feet tucked up in order to keep them warm. In very cold weather Canada Geese have been observed to tuck their feet forward and under their feathers in a similar fashion instead of carrying them back under their tail as they usually do when in flight, but we know of no previous report of this interesting habit in Sandhill Cranes. 